\title{
$\mathrm{CE}$ 기법을 적용한 수목원의 편익제공 가치 추정 연구 ${ }^{\dagger}$ - 경남수목원을 대상으로 -
}

강기래

부산대학교 생명산업융합연구원

\section{A Study on the Estimation of Values of Individual Services of an Arboretum using the CE Method \\ - Focused on Gyeongnam Arboretum -}

\author{
Kang, Kee-Rae
}

Institute of Comprehensive Bio Industrial, Pusan National University

\begin{abstract}
This study was conducted to compare the sizes of effective values, which users recognize, according to the kinds of physical and psychological services provided by an arboretum, by estimating them in monetary values.

As an analysis tool for this purpose, the CE(Choice Experiments) method, which is able to estimate effective value's size depending on each variable, was employed. For drawing up profiles for estimation of the values of individual services, 25 profiles were extracted using the orthogonal design of the SPSS statistical package, and questions of 75 pairs were created not to make each of the profiles overlapped. Then, each user was given three questions at five sets each and 3,510 data were used for the analysis.

As the result, in relation to the attribute, 'The kinds of trees should be diversified 50\% more than now.', firstly, users showed the biggest willingness to pay, based on the present level, and expressed intentions to pay 7,956 won, additionally.

Secondly, the value of the path design that was unique than the present road design was estimated in 6,025 won, and when individual attendants guided visitors in the arboretum, they expressed intentions to pay nearly three times more expenses than when they were guided as a group.

These results show that users in the Gyeongnam Arboretum recognized the highest effective values towards the collection and display of trees that are arboretum's original functions, and it was followed by the unique road design to observe a variety of dense trees well.

This research could be useful in comparing or measuring particular effective values of users that central operators of arboretums want to know. Moreover, it would be suggested as an advanced research for providing basic data about value estimation of individual environmental goods not only in arboretums, but also in other fields.
\end{abstract}

Key Words: Willingness to Pay, Effective Value, Central Operator, Environmental Goods

\footnotetext{
${ }^{\dagger}$ : 이 논문은 2011년 한국조경학회 춘계학술대회 발표 논문을 수정 보완하였음.
}

Corresponding author: Kee-Rae Kang, Institute of Comprehensive Bio Industrial, Pusan National University, Kyungnam 627-706, Korea, Tel.: +82-10-3823-8345, E-mail: kr4yn@naver.com 


\section{국문초록}

본 연구는 수목원이 제공하는 물리적, 심리적인 서비스를 그 종류에 따라 이용객이 인식하는 효용가치를 화폐액으로 추산하여 그 크기를 비교해 보고자 수행되었다. 목적을 위한 분석의 도구는 각각의 변수에 따른 효용가치의 크기를 추산해 낼 수 있는 $\mathrm{CE}$ (Choice Experiments) 기법을 이용하였다. 개별서비스의 가치추정을 위한 프로파일의 작성은 SPSS 통계패키지 의 직교설계를 이용하여 25 개의 프로파일을 추출하여 각각의 프로파일이 중복되지 않도록 75 쌍의 질문 항을 만들어 1 인당 5 세트씩, 3 개의 문항을 질문하여 3,510 개의 자료를 분석에 이용하였다.

연구의 결과, 현재의 수준을 기준으로 한 이용객의 지불의사액이 가장 큰 속성은 '현재보다 수목의 종류를 $50 \%$ 더 다양하게'하는 속성이 7,956원의 추가적 지불의사를 나타내고 있다. 그리고 두 번째가 현재의 원로 디자인보다 매우 독특한 원로디자인의 가치가 6,025 원으로 나타났으며, 수목원 관람 시 개인 안내원이 가이드를 해 주는 것이 단체로 안내해 주는 것보다 약 3 배 정도 더 많은 추가비용을 지불할 의사가 있는 것으로 나타났다.

이를 통해 경남수목원의 이용객들이 가치를 높게 인식하는 것은 수목원 본래의 기능인 수목의 수집과 전시기능에 가장 높은 효용가치를 느끼고 있음을 알 수 있으며, 그 다음으로 다양하고 울창한 수목을 잘 관찰할 수 있는 독특한 원로의 디자인에 그 가치를 두고 있음을 알 수 있다.

본 연구는 수목원 운영주체에서 알고자 하는 이용객의 특정한 효용의 가치를 비교 또는 측정해 보고자 할 경우, 유용한 방법이 될 수 있을 것이다. 또한 수목원뿐만 아니라 타분야의 개별 환경재의 가치추정에 대한 기초자료의 제공을 위한 선행연구의 개념으로 제시되어질 것이다.

주제어: 지불의사액, 효용가치, 운영주체, 환경재

\section{I. 서론}

산업화로 인한 인류의 생활양식은 대량 생산, 대량소비가 미 덕으로 여겨졌으며, 자연은 인류의 편의를 위한 개발의 대상으 로 인식되어 왔다. 도시의 확장은 멈추는 것을 잊었고, 자연의 보존은 개발이라는 미명아래 소외되어 왔다. 이와 같은 급속한 도시화의 진행으로 인한 자연의 파괴는 인류에게 제공하던 생 태 수용력을 잃어 가고 있다는 인식이 서구 산업화의 선진국에 서부터 시작되었다. 이러한 위기의식으로 멸종되어 가는 희귀 야생 식물에 대한 보존의 중요성이 식물원이라는 시설로 나타 나고 있다. 서구에서는 네덜란드의 Leiden(1587년) 수목원, 영 국의 Kew(1759) 수목원 등 이미 16세기부터 식물을 하나의 자 원으로 인식하여 체계적인 수집과 육종, 관리를 해 왔으나, 우 리나라는 수목원의 기본적 기능을 가진 홍릉수목원이 1922년 에 개장되었고, 뒤이어 현대적 개념을 가진 서울대학교 관악수 목원이 1967년에 개장하였다.

우리나라의 수목원 수는 한국 식물원 - 수목원협회 기준으로 2011년 말 현재 54개소이며, 이 중 국립수목원 1개소, 공립수목 원 34 개소, 학교수목원 6 개소, 사립수목원 13 개소이다. 수목원 조성 및 진흥에 관한 법률에 “수목원”이란 수목을 중심으로 수 목유전자원을 수집 · 증식 · 보존 · 관리 및 전시하고, 그 자원화 를 위한 학술적-산업적 연구 등을 하는 시설이라고 규정하고 있다. 이러한 수목원의 기능 중 현대인들이 생활 가까이에서 식
물에 대한 정보와 여가생활을 누리기 위한 수목자원의 전시와 교육에 대한 중요성이 점점 더 높아지고 있다. 이에 따라 우리 나라 대부분의 수목원은 그 고유기능인 수집 · 증식 · 보존 · 관 리의 역할뿐 아니라, 전시와 교육을 위한 부서를 따로 만들어 식물에 대한 교육과 전시를 담당하고 있다.

근래 들어 국민들의 생활수준 향상과 여가패턴의 변화로 자 연환경을 직접 체험하고자 수목원과 식물원에 대한 수요가 급 증함에 따라, 기존 운영 체계의 개선 및 자연 교육프로그램 개 발 등 다양한 변화가 시급히 요구되는 실정(하성근, 2007)이며, 각각의 수목원의 특성을 살리는 일은 매우 중요한 일이다. 우 리나라의 수목원들도 이제까지의 관형적인 관리운영과 설계, 조성방법에서 벗어나 수목원마다 각각의 특화된 역할을 찾아 내고, 기능을 전문화해야 하는 전환의 시기(국립수목원, 2004) 라고 할 수 있다.

수목원이 이용객에게 제공할 수 있는 물리적 요소들은 수목 의 종류를 다양하게 하고, 아름답고 깨끗한 경관을 만들고, 산 책을 위한 원로의 디자인을 새롭게 하거나 또는 수목에 대한 안내를 방문객에게 제공하는 방법 등을 생각해 볼 수 있다. 이 에 따라 본 연구는 이용객의 입장에서 수목원이 가진 특정 재 화나 서비스를 개선시키면 그 대가로 얼마를 더 추가로 지불할 의사가 있는지를 추정해 보기 위해 수행되었다. 이러한 연구는 수목원이 제공하는 물리적이나 심리적인 서비스를 그 종류에 따라 금액으로 추정하기 위한 목적이다. 
연구를 위한 도구는 각각의 변수에 따른 효용가치의 크기를 추산해 낼 수 있는 $\mathrm{CE}$ (Choice Experiments) 기법을 이용하였 으며, 도출된 결과는 서비스별로 효용의 크기를 나타내 줄 수 있기 때문에 향후 수목원의 물리적 시설이나 서비스의 개선을 진행할 경우, 우선순위를 제공해 줄 수 있을 것이다. 또한 향후 각 시설과 서비스의 효용성을 검토하거나 그 크기를 비교할 경 우, 유용한 기초자료의 제공을 위한 선행연구의 개념으로 제시 되어질 것이다.

\section{II. 이론적 배경}

\section{1. 환경재와 가치추정}

환경재 또는 비시장재는 거래가 불가능하기 때문에 시장가 격이 형성되지 않는다. 따라서 시장 수요곡선도 존재하지 않으 며, 환경재의 가치를 측정하는 문제는 많은 학자들 간에 논란 의 대상이 되어 왔으며, 다양한 측정방법도 제시되고 있다. 환 경재가치의 측정방법은 크게 직접평가방법과 간접평가방법으 로 구분할 수 있다. 직접평가방법은 이해 당사자에게 직접 문 의하여 조사하는 방법인 반면, 간접평가방법은 관련 시장재화 의 수요변화를 관찰하여 유추하는 방법을 통칭한다(박주헌, 2000). 환경재의 가치평가방법을 크게 구분하면 표 1 과 같다.

직접평가 방법 중 선택실험법의 이론적 바탕은 $\mathrm{CVM}$ 과 마 찬가지로 Hicks적 확률효용모델(Random Utility Model)이다. 추정방법의 기본은 여러 개의 속성으로 이루어진 질문에 따라 개인의 효용의 크기가 최대가 되는 선택을 하게 되는 속성의 가 치를 구분하는 것이다. 이러한 질문은 각각의 속성이 가진 효용 의 크기를 측정하기 위해 연구자는 상충관계(trade-off)에 있는 선택의 속성을 이용하여 추정액을 도출하게 된다(강기래, 2012).

$\mathrm{CVM}$ 에서의 환경재의 가치 추정은 양분 선택형 가상가치평 가법(Dichotomous choice contingent valuation method)이며, 이는 무작위로 제시된 금액 $\mathrm{A}$ 를 소비자의 지불의사에 의한 수 용, 거부만으로 자료를 획득하여 확률모델로 전환하여 지불의 사금액 함수를 추정하고, 이를 효용이론(Utility theory)에 접목

표 1. 환경재의 가치측정 방법 (강기래, 2010: 27)

\begin{tabular}{|c|c|c|}
\hline \multicolumn{2}{|r|}{ 종류 } & 적용 대상 및 방법 \\
\hline \multirow{2}{*}{$\begin{array}{c}\text { 직접평가 } \\
\text { 방법 }\end{array}$} & CVM & 직, 간접적인 모든 종류의 편익 측정 가능 \\
\hline & $\mathrm{CE}$ & $\begin{array}{l}\text { 직, 간접적인 편익의 측정과 그 속성까지 } \\
\text { 구분하여 측정 가능 }\end{array}$ \\
\hline \multirow{3}{*}{$\begin{array}{l}\text { 간접평가 } \\
\text { 방법 }\end{array}$} & 헤도닉 가격법 & $\begin{array}{l}\text { 시장가격에 포함되어 있는 환경재의 가치를 } \\
\text { 추정 }\end{array}$ \\
\hline & 여행 비용법 & 여행비용으로 환경재, 관광지의 가치를 추정 \\
\hline & 회피행위 지출법 & $\begin{array}{l}\text { 환경의 변화를 개선하기 위해 투입되는 비용 } \\
\text { 을 측정 }\end{array}$ \\
\hline
\end{tabular}

시켜 소비자의 후생변화를 측정하는 방법이다(Hanemann, 1984). $\mathrm{CVM}$ 과 $\mathrm{CE}$ 기법의 차이는 환경재를 이루고 있는 개개의 속성 별 가치를 측정할 수 있는지로 구분할 수 있다. CVM은 특정 환경재의 전체 가치를 추정할 수 있으나. $\mathrm{CE}$ 기법은 특정 환경 재를 이루고 있는 개개의 속성별 가치를 구분하여 추정할 수 있다.

\section{2. $\mathrm{CE}$ 기법의 이론적 배경}

$\mathrm{CE}$ 기법은 측정하고자 하는 환경재를 구성하고 있는 속성들 의 수준과 가격의 조합으로 이루어진 프로파일을 구성하여 질 문자에게 제시하게 되고, 질문자는 각각의 조합들 중에서 효용 의 크기가 최대가 되는 선택을 하게 된다. 개인이 경남수목원 을 방문하여 현재보다 추가로 얻게 되는 효용을 최대화시키는 모형은 식 1 과 같다.

$$
U_{i A}=V_{i A}+\epsilon_{i A}
$$

여기서 $U_{i A}$ : 응답자 $A$ 의 $i$ 번째 프로파일로부터 얻는 총 효용 $V_{i A}$ : 관측 가능한 응답자 $A$ 의 $i$ 번째의 효용 $\epsilon_{i A}$ : 관측 불가능한 응답자 $A$ 의 $i$ 번째의 오차항

모든 결정에서 연구자는 관찰 가능한 정보와 관찰 불가능한 정보로 구분할 수 있다. 만약 응답자 $A$ 가 주어진 프로파일 집 합 $N$ 에 대해 $U_{i A} \geq V_{j A}(i, j \in N, i \neq j)$ 의 조건을 만족할 경 우, $i$ 번째 프로파일을 선택할 것이며 응답자 $A$ 가 선택할 확률 은 식 2 와 같이 표현할 수 있다.

$$
\begin{aligned}
\operatorname{Pr}_{i A} & =\operatorname{Pr}\left[V_{i A}+\epsilon_{i A} \geq V_{j A}+\epsilon_{j A}\right] \\
& =\operatorname{Pr}\left[V_{i A}-V_{j A} \geq \epsilon_{j A}-\epsilon_{i A}\right]=\operatorname{Pr}\left[\Delta V_{A} \geq \Delta \epsilon_{A}\right] \\
& =F_{\eta}(\Delta V) \quad(0 \leq \operatorname{Pr} \leq 1)
\end{aligned}
$$

여기서 $\operatorname{Pr}[\cdot]$ : 확률

$\triangle V:$ 가치의 변화량

$\Delta \epsilon$ : 효용의 변화량

위의 식 2에서 $V$ 는 관측 가능한 선형함수, $\epsilon_{i A}$ 는 제시된 옵 션 1 과 2 를 선택하는 확률의 비율은 3 번 무옵션 선택의 결정에 영향을 미치지 않는 옵션간의 독립성 조건을 취한다고 가정한 다. $\epsilon_{i A}$ 는 옵션에 따른 응답자의 결정에 대한 설명과 관측되지 않은 오차를 잘 표현할 수 있는 Gumbel 분포를 따른다고 가정 하면 식 3과 같은 조건부 로짓 확률모형을 도출할 수 있다(강 
기래, 2012)

$$
\operatorname{Pr}_{i A}=\frac{\operatorname{EXP}\left(V_{j A}\right)}{\sum_{j=1}^{J} \operatorname{EXP}\left(V_{j A}\right)}
$$

여기서 $V_{i A}$ 의 형태를 경남수목원의 방문 및 관람의 옵션에 유도하면 식 4 와 같은 선형함수가 된다.

$$
V_{i A}=\left[\begin{array}{l}
\left(\beta_{p r} \cdot \text { PRIC }_{i A}\right)+\left(\beta_{\text {peguide }} \cdot \text { PEGUIDE }_{i A}\right)+\left(\beta_{\text {grguide }} \cdot \text { GRGUIDE }_{i A}\right) \\
+\left(\beta_{\text {pathde }} \cdot \text { PATHDE }_{i A}\right)+\left(\beta_{\text {plspec }} \cdot \text { PLSPEC }_{i A}\right)
\end{array}\right]
$$

여기서 $V_{i A}=$ 개인 $A$ 의 $i$ 번째의 효용

$\beta_{p r}=$ 옵션 구입액의 효용계수

$P R I C_{i A}=$ 옵션구입액의 속성수준

$\beta_{\text {peguide }}=$ 개인안내원의 효용계수

$P E G U I D E_{i A}=$ 개인안내원의 속성수준

$\beta_{\text {grguide }}=$ 단체안내원의 효용계수

$G R G U I D E_{i A}=$ 단체안내원의 속성수준

$\beta_{\text {pathde }}=$ 산책로 디자인의 효용계수

$P A T H D E_{i A}=$ 산책로 디자인의 속성수준

$\beta_{\text {plspec }}=$ 수목종류 다양함의 효용계수

$P L S P E C_{i A}=$ 수목종류 다양함의 속성수준

이용자가 원하는 수목원의 속성별 수준에 따라 1 단위 개선 되었을 때의 효용의 가치를 한계지불의사액의 개념을 이용하 여 식 5와 같이 도출할 수 있다(Haab and Mcconnell, 2002).

$$
\text { Marginal } W T P=-\frac{\triangle u \beta}{\beta_{p r}}
$$

여기서 $\beta_{p r}=$ 옵션구입의 한계 지불액 $\triangle u \beta=$ 각 옵션에 따른 효용의 변화량

\section{표 2. 수목원 개선 편익별 가치추정식}

\begin{tabular}{c|c|c|c}
\hline 한계지불액 & 편익의 종류와 속성 & 기호 & 편익별 한계 지불액 \\
\hline \multirow{4}{*}{$-\beta_{p r}$} & 개인 안내원(있음, 없음) & $\beta p e$ & $-\beta p e / \beta_{p r}$ \\
\cline { 2 - 4 } & 단체안내원(있음, 없음) & $\beta g r$ & $-\beta g r / \beta_{p r}$ \\
\cline { 2 - 4 } & 원로디자인의 수준(3단계) & $\beta_{d e}$ & $-\beta_{d e} / \beta_{p r}$ \\
\cline { 2 - 4 } & 수목 종류의 수준(3단계) & $\beta s p$ & $-\beta s p / \beta_{p r}$ \\
\hline \multicolumn{3}{|c|}{ Tatal WTP } & 전체의 합 \\
\hline
\end{tabular}

주어진 수식을 바탕으로 각각의 옵션에 대한 지불 의사액은 표 2와 같이 산출할 수 있다. 지불의사액인 $\beta_{p r}$ 가 음 $(-)$ 의 부 호인 것은 가격이 상승함에 따라 소비자의 효용이 감소(-)하 기 때문이다.

\section{3. 선행연구 고찰}

우리나라 최초의 창경궁의 식물원은 관상용 전시장의 수준 을 넘어 서지 못하였으며, 수목원의 기초적 개념을 가진 홍릉 수목원이 1922년에 개원하였으며, 현대적 개념의 수목원은 1967 년 개원한 서울대학교 관악수목원이라고 할 수 있다. 이후 각 학교나 지방자치단체나 민간에서 식물원의 조성이 활발하게 이루어졌으며, 이러한 변화와 더불어 수목원에 대한 연구들도 많이 진행되어 오고 있다. 수목원에 대한 조기의 연구들은 우 리나라 식물원 설립 초기 식물 목록을 주류로 한 연구들, 특히 이창복(1972)의 식물 목록에 대한 연구가 시도되었다. 이후 홍 릉수목원의 보유식물들의 개화기를 조사하여 각 식물의 개화 시기와 꽃이 피는 기간 및 식물의 생육상을 연구한 임양재와 조무연(1977)이 있으며, 이총규 등(2006)은 경남수목원 내의 수목병해충에 대한 연구를 수행하였다. 이 연구에서 경남수목 원내의 가해 해충은 70 종이 있으며, 이 중 피해를 많이 입히는 해충은 목화진딧물, 소나무가루깍지벌레, 밤나무왕진딧물, 복숭 아흑진딧물, 목화진딧물, 솔잎혹파리, 장미등애잎벌, 그리고 진 달래방패벌레 등이었다.

나정화(2000)는 헤메로비등급을 이용한 대구수목원 조성전 후의 자연성평가에 대한 연구를 수행하였다. 이 연구에서 수목 원 조성 전의 헤메로비 등급은 인간의 간섭이 매우 심한 metahemeroby 등급이 높았으나, 수목원 조성 후의 등급은 비교적 높은 자연성을 보여주는 $\alpha$-Hemeroby 등급이 생기는 것을 연 구하였다. 이는 대구수목원은 나지와 같은 상태인 쓰레기 매립 장은 수목원으로 조성하였기 때문에 자연성이 높아졌다고 볼 수 있다. 조우 등(2003)은 인천광역시 식물원 조성애 대한 기 본계획에 대한 연구를 수행하였다.

이용객들의 이용행태와 만족도를 통한 관리방안에 대한 연 구들은 비교적 활발히 이루어지고 있으며(임연진 등, 2005; 백 동렬 등, 2003; 강기래, 2012), 이들 연구의 공통적인 시사점은 수목원의 물리적 기능인 식물의 다양화, 시설의 청결, 수목 해 설가의 배치, 수목원의 환경에 대한 교육 프로그램 등의 도입 을 바라고 있으며, 이는 수목원의 가치를 증대시키는 효율적인 방법이라고 할 수 있다. 이 외에 수목원의 환경적 가치(강기래 등, 2010; 홍성권 등 2010)에 대한 연구도 진행되어 다양한 분 야로 확대되고 있음을 알 수 있다. 이 중 홍성권 등(2010)은 새 로 설립될 예정인 세종시 수목원에 대한 수준별 속성과 중요성 에 대한 연구에서 이용객들은 일반적인 육지식물보다 생물다 양성이 풍부한 습지식물원을 조성하였을 경우 1,330 원을 추가 
로 더 낼 의사가 있으며, 산책로를 호기심 있게 다양하게 설계 했을 경우도 1,507 원을 더 지불할 의사가 있음을 연구하였다. 본 연구와의 차이점은 실제 운영 중인 수목원의 시설과 서비스 의 개선에 대한 접근과 새로 설립 예정인 수목원의 운영지표와 수목원의 속성에 대한 차이이다. 홍성권 등(2010)의 연구와 동 일한 부분은 수목의 다양화와 원로 디자인의 독특함에 가장 많 은 지불의사를 보인다는 점이다.

하지만 이러한 다양한 분야에 대한 수목원의 연구 중에서 운 영하고 있는 수목원에서 제공하는 물리적, 환경적 서비스와 시 설물에 대한 각각의 효용의 가치에 대한 연구들은 아직 이루어 지지 않고 있다.

\section{III. 연구의 범위 및 방법}

\section{1. 연구의 범위}

본 연구는 수목원의 다양한 기능에 대한 지불의사를 질문함 으로써 각각의 수준에 따른 가치를 구분하여 추정할 수 있는 $\mathrm{CE}$ 기법을 적용하여 그 가치를 추산하고자 수행되었으며, 연 구의 물리적 범위는 경상남도산림환경연구원 산하 경남수목원 으로 한정하였다. 그 이유는 2011년 12월 한국식물원수목원협 회 기준 전국 수목원은 54 개소이며, 이들 수목원 전부를 조사 하기에는 시간적 비용적 문제 및 연구의 효율성에 대한 문제로 특정 수목원을 좀 더 세밀하게 연구하여 결과의 충실성을 도출 할 수 있을 것이다. 이에 따라 경남수목원을 기준으로 하여 선 택실험법의 적용성을 검토하여, 전국 수목원으로 확대해 나갈 수 있을 것이다.

경남수목원은 경상남도 이반성면에 소재하고 있으며, $112 \mathrm{ha}$ 의 면적으로 1989년에 임업시험장으로 시작하여 1993년에 도 립반성수목원으로 개장하였다. 정식명칭은 경상남도산림환경 연구원이며, 한국식물원수목원협회에는 경남수목원으로 등록되

표 3. 경남수목원의 일반적 사항

\begin{tabular}{|c|c|c|}
\hline \multicolumn{2}{|c|}{ 구분 } & 내용 \\
\hline \multicolumn{2}{|c|}{ 위치 } & 경상남도 이반성면 수목원로 386 \\
\hline \multicolumn{2}{|c|}{ 면적 } & $58 \mathrm{ha}$ 건물: 산림박물관 등 32 동 $12,435 \mathrm{~m}^{2}$ \\
\hline \multicolumn{2}{|c|}{ 보유 수종 } & 화목 2,600여종 \\
\hline \multicolumn{2}{|c|}{ 부대 시설 } & $\begin{array}{c}\text { 전문수목원, 산림박물관, 야생동물원, 산림표본관, } \\
\text { 증식온실, 무궁화홍보관 }\end{array}$ \\
\hline \multirow{5}{*}{$\begin{array}{c}\text { 연간 } \\
\text { 이용객 }\end{array}$} & 2007 & 567,430 \\
\hline & 2008 & 586,665 \\
\hline & 2009 & 410,042 \\
\hline & 2010 & 450,055 \\
\hline & 2011 & 510,055 \\
\hline \multicolumn{2}{|c|}{ 계 } & 5년간 연 평균 방문객수: 504,849 \\
\hline
\end{tabular}

어 있다. 보유시설은 산림박물관을 포함한 38 개동이 있으며, 보 유 수목은 약 2,600여 종이다. 기타의 부대시설은 산림박물관, 산 림표본관, 야생동물원, 방문자센터, 숲속교실, 유전자증식온실 등을 보유하고 있으며, 연간 이용객은 매년 약 50 여만 명이다.

\section{2. 연구의 방법}

연구의 방법은 수목원이 제공하는 물리적 시설과 서비스에 대한 개별 가치를 추정하기 위한 도구의 적용, 그리고 각각의 가치를 추정하기 위한 물리적 시설과 서비스의 수준의 결정, 그리고 이용자의 입장에서 각각의 속성과 수준별로 구성된 프 로파일의 선호도와 지불의사액에 따라 각 서비스의 가치를 추 정 비교하는 순서로 진행된다. 개별가치추정을 위한 프로파일 의 선택을 위한 표본의 추출은 경남수목원 방문객들 중 계절별 이용객을 일부 고려하여 무작위추출법(random sampling)을 이용하여 질문하였다.

경남수목원에서 제공하는 물리적 시설과 서비스의 종류는 전문가 브레인스토밍 과정을 거쳐 수목의 종류, 산책로, 원로의 디자인, 개인안내원, 단체안내원의 4 가지 속성으로 선정하였으 며, 이에 따른 추가 지불요금은 4단계로 정하였다. 추가지불요금 은 강기래 등(2011)의 경남수목원 평균 방문비용인 약 20,000 원 및 성인 입장료인 1,500 원을 고려하여 추가로 지불할 의사 액을 200 원. 400 원, 800 원, 1,600 원 4단계로 설정하였으며, 속성 의 수준은 표 4 와 같이 지정하였다. 옵션의 형태로 제시된 프로 파일은 1 인당 5 세트의 프로파일을 제시하여 설문하였으며, 하 나의 세트에는 1 번 옵션, 2 번 옵션, 3 번 무응답 또는 1, 2번 비 선택 옵션의 세 가지 선택 사항이 있다.

경남수목원의 편익제공에 따른 가치분석을 위한 설문의 조 합은 표 4에 구분된 수목원 속성별 수준별 지불의사 선택 조합 의 수를 이용하여 144 개 $(2 \times 2 \times 3 \times 3 \times 4)$ 의 조합을 만들 수 있다.

표 4. 추가요금 지급 사항을 위한 변수

\begin{tabular}{|c|c|c|}
\hline 속성 & 속성 수준 & 속성 설명 \\
\hline $\begin{array}{c}\text { 개인 } \\
\text { 안내원 }\end{array}$ & $\begin{array}{l}0: \text { 없다 } \\
1: \text { 있다 }\end{array}$ & 일대일로 수목원의 안내와 수목에 대한 설명 \\
\hline $\begin{array}{c}\text { 단체 } \\
\text { 안내원 }\end{array}$ & $\begin{array}{l}0: \text { 없다 } \\
1: \text { 있다 }\end{array}$ & 단체로 수목원의 안내와 수목에 대한 설명 \\
\hline $\begin{array}{l}\text { 원로 } \\
\text { 디자인 }\end{array}$ & $\begin{array}{c}\text { 1: 현재 상태 } \\
\text { 2: 약간 독특함 } \\
3: \text { 아주 독특함 }\end{array}$ & 수목원의 동선에 대한 디자인 \\
\hline $\begin{array}{l}\text { 수목의 } \\
\text { 종류 }\end{array}$ & $\begin{array}{l}\text { 1: 현재 상태 } \\
\text { 2: } 20 \% \text { 향상 } \\
\text { 3: } 50 \% \text { 향상 }\end{array}$ & 현재 기준 수목원의 수목의 종류와 다양성 \\
\hline $\begin{array}{l}\text { 추가 } \\
\text { 지불요금 }\end{array}$ & $\begin{array}{c}\text { 1: 200원 } \\
2: 400 \text { 원 } \\
3: 800 \text { 원 } \\
4: 1,600 \text { 원 }\end{array}$ & $\begin{array}{c}\text { 향후 재 방문 시 관련 조건에 따른 추가로 } \\
\text { 더 지불할 의사 금액 }\end{array}$ \\
\hline
\end{tabular}


표 5. 프로파일 조합을 통한 질문의 예시

질문 1: 선호 프로파일

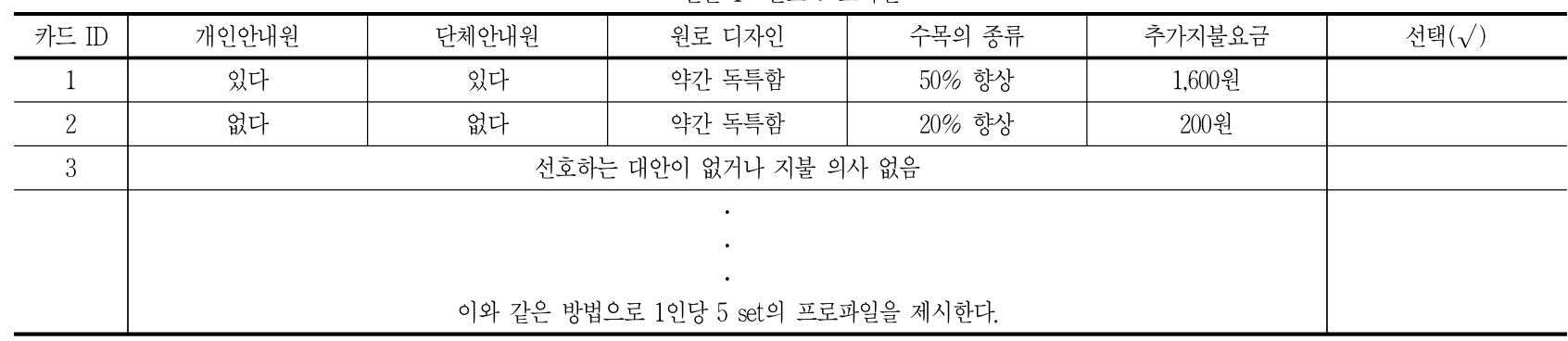

하지만 현실적으로 144 개의 조합을 응답자에게 설문한다는 것 은 매우 어렵기 때문에 SPSS 프로그램 직교설계를 통해 25개 의 프로파일을 추출하여 각각의 프로파일이 중복되지 않도록 75 쌍의 질문 항을 만들어 조사에 활용하였다. 추출된 프로파일 조합은 표 5 와 같이 작성하여 1 인당 $5 \mathrm{set}$ 를 질문하였다.

\section{IV. 수목원의 편익제공 가치분석}

\section{1. 이용객의 일반적 사항}

경남수목원의 편익 제공에 따른 환경가치 추정을 위한 설문 의 기간은 2011년 5월부터 2012년 4월에 걸쳐 경남수목원을 방 문하는 방문객 234 명에게 개별면접을 통하여 수목원의 시설 및 운영의 향상을 통한 가치 추정액을 도출하였다. 관측된 자료를 1 인당 5 세트씩, 3 개의 문항을 질문하여 총 3,510 개의 자료를 바 탕으로 상충효과를 이용한 개별가치 추정액을 도출하였다. 설 문 응답자의 일반적 사항은 표 6 과 같다.

\section{표 6. 응답자의 일반적 특징}

\begin{tabular}{|c|c|c|c|c|c|c|c|}
\hline 구분 & 내용 & 빈도 & $\%$ & 구분 & 내용 & 빈도 & $\%$ \\
\hline \multirow{2}{*}{ 성별 } & 여성 & 137 & 58.5 & \multirow{5}{*}{$\begin{array}{l}\text { 방문 } \\
\text { 소요 } \\
\text { 시간 }\end{array}$} & 1시간 이내 & 134 & 57.3 \\
\hline & 남성 & 97 & 41.5 & & 2시간 이내 & 75 & 32.1 \\
\hline \multirow{6}{*}{ 연령 } & 20대 이하 & 13 & 5.6 & & 3시간 이내 & 22 & 9.4 \\
\hline & 20대 & 59 & 25.2 & & 4시간 이내 & 2 & 0.9 \\
\hline & 30대 & 58 & 24.8 & & 4시간 이상 & 1 & 0.4 \\
\hline & 40대 & 67 & 28.6 & \multirow{5}{*}{ 동행인 } & 가족, 친지 & 67 & 28.6 \\
\hline & 50대 & 29 & 12.4 & & 친구 & 44 & 18.8 \\
\hline & 50대 이상 & 8 & 3.4 & & 동료, 동호회 & 57 & 24.4 \\
\hline \multirow{5}{*}{$\begin{array}{l}\text { 방문 } \\
\text { 횟수 }\end{array}$} & 1회 & 72 & 30.8 & & 연인 & 21 & 9.0 \\
\hline & 2회 & 58 & 24.8 & & 학교 학원 & 45 & 19.2 \\
\hline & 3회 & 46 & 19.7 & \multirow{5}{*}{$\begin{array}{l}\text { 방문 } \\
\text { 비용 }\end{array}$} & 5,000 원 이하 & 65 & 27.8 \\
\hline & 4회 & 20 & 8.5 & & 10,000 원 이하 & 76 & 32.5 \\
\hline & 5회 이상 & 38 & 16.2 & & 20,000 원 이하 & 57 & 24.4 \\
\hline \multirow{2}{*}{$\begin{array}{l}\text { 방문 } \\
\text { 형태 }\end{array}$} & 단체 & 121 & 51.7 & & 40,000 원 이하 & 17 & 7.3 \\
\hline & 개별 & 113 & 48.3 & & 40,000 원 이상 & 19 & 8.1 \\
\hline
\end{tabular}

경남수목원을 방문하는 방문객은 비교적 고른 연령대를 보 이고 있으며, 방문횟수는 1 회 또는 2회 방문한 이용객이 가장 많은 빈도를 보이고 있다. 경남수목원은 진주, 창원 등 대도시 에서 1시간 이내에 도착할 수 있는 거리에 위치하고 있기 때문 에 가족이나 친지 또는 친구들과의 방문이 가장 많은 빈도를 보이고 있다. 그리고 방문 비용 또한 20,000원 이하가 대부분을 차지하고 있음을 알 수 있다.

\section{2. 속성별 효용가치의 추정}

경남수목원에서 제공하는 개별 속성의 가치는 조건부 로짓 (Conditional Logit) 모형으로 추정하였다. 로짓모형을 적용하 기 위해서 더미 변수를 이용하여 각 기술의 속성과 수준을 표 7에 정리하였다. 조건부 로짓모형의 장점은 예측변수에 범주형 변수를 투입할 수 있다는 장점이 있으며, 이를 위해 더미변수 를 이용하여 변수를 범주형으로 변환시킨다. 수목원에서 제공 할 수 있는 개인안내원, 단체안내원, 원로의 디자인, 수목의 종 류 4 가지 속성의 수준을 정하였다. 개인과 단체 안내원은 있음 과 없음, 원로의 디자인과 수목의 종류는 3 단계의 수준을 정하 였다. 이는 현재의 수준에서 더 나은 효용을 제공했을 경우를 산정한 것이다. 경남수목원이 제공하는 물리적 시설과 서비스 의 종류에 따른 이용객의 선택은 조건부 로짓모형으로 그 가치의 크기를 추정할 수 있으며, 사용된 통계패키지는 SPSS Statistics ver. 19.0(SPSS INC. 1999) 와 Stata 10.0(StataCorp LP, 2007)

표 7. 변수의 속성과 수준의 정의

\begin{tabular}{c|c}
\hline 속성수준 & 정의 \\
\hline 개인 안내원(personal guide) & 없다: 0, 있다: 1 \\
\hline 단체 안내원(group guide) & 없다: 0, 있다: 1 \\
\hline 원로디자인(path design)1 & 평범함: 0 , 약간 독특: 1, 아주 독특함: 0 \\
\hline 원로디자인(path design)2 & 평범함: 0, 약간 독특: 0, 아주 독특함: 1 \\
\hline 수목의 종류(plant species)1 & 변동 없음: $0,20 \%$ 향상: $1,50 \%$ 향상: 0 \\
\hline 수목의 종류(plant species)2 & 변동 없음: $0,20 \%$ 향상: $0,50 \%$ 향상: 1 \\
\hline 가격(price) & 200 원, 400 원, 800 원, 1,600 원 \\
\hline
\end{tabular}


프로그램을 이용하였다.

통계처리 패키지는 프로그램의 유연성이 탁월한 STATA 프로그램을 이용하였다. 각 기술에 대한 조건부 로짓 추정결과, 수준별 효용계수와 $t$-value, 유의확률 등을 표 8에 제시하였다. 각각의 변수에 대한 유의성은 $95 \%$ 유의수준에서 유의미한 결 과를 나타내고 있으며, 가격의 변수를 음 $(-)$ 의 부호를 나타내 고 있다. 이는 제시 금액이 높아질수록 음 $(-)$ 의 상관관계가 있 음을 의미한다. 또한 95\% 신뢰수준에서의 상한값(upper layer) 과 하한값(lower layer)을 나타내주고 있다. 또한 로짓모형의 적합도를 나타내는 우도함수(Log-Likelihood)는 -1,979.3124로 그 값이 작을수록 더 적합하다(노형진, 2001)고 할 수 있다.

표 8을 이용하여 수목원 효용의 속성과 수준에 대한 가치를 추정할 수 있다. 추정식은 전술한 $-\frac{\triangle u \beta}{\beta_{p r}}$ 를 이용하여 각 효 용에 대한 가격과 수준을 정리하여 표 8에 제시하였다. 효용의 수준은 일대일 개별안내원이 수목에 대한 설명과 안내를 해 줄 경우 3,800 원을 추가로 더 지불할 의사가 있으며, 단체로 안내 를 해 줄 경우 1,163 원을 추가로 지불할 의가가 있음을 나타내 주고 있다. 또한 원로의 디자인과 수목의 종류에 따라 그 효용 가치가 달라지고 있다.

이와 같은 효용의 가치를 현재의 수준을 기준으로 재정리하 여 표 10 에 제시하였다. 현재의 기준에서 수목의 종류가 $50 \%$
표 10. 수목원의 서비스에 따른 효용의 가치순위

\begin{tabular}{|c|c|c|}
\hline 순위 & \begin{tabular}{|c|} 
편익의 \\
가치(원)
\end{tabular} & 효용의 수준과 정의 \\
\hline 1 & 7,956 & 수목의 종류가 현재보다 $50 \%$ 많아질 때의 지불의사액 \\
\hline 2 & 6,025 & 현재의 수준에서 아주 독특한 원로디자인으로의 변화가치액 \\
\hline 3 & 4,599 & 현재의 수준에서 수목의 종류가 $20 \%$ 항상시의 지불의사액 \\
\hline 4 & 3,800 & 일대일로 수목원의 안내와 수목에 대한 설명에 대한 효용액 \\
\hline 5 & 3,226 & $\begin{array}{l}\text { 원로의 디자인이 현재의 수준에서 약간 독특한 디자인으 } \\
\text { 로의 변화 가치액 }\end{array}$ \\
\hline 6 & 1,163 & $\begin{array}{l}\text { 단체로 수목원의 안내와 수목에 대한 설명에 대한 효용 } \\
\text { 가치액 }\end{array}$ \\
\hline
\end{tabular}

더 많아질 경우를 예로 들면, 효용의 가치는 $20 \%$ 향상된 가치 3,357 원과 $50 \%$ 로 향상된 가치 4,599 원을 합한 7,956 원이 방문 객이 추가로 지불할 의사액이 된다. 이와 같이 계산된 결과, 경 남수목원 방문객이 추가로 지불할 금액이 가장 높은 순위는 수 목의 종류를 현재보다 $50 \%$ 더 다양하게 전시할 경우의 추가지 불 의사액이 가장 높다. 그리고 현재의 원로디자인에서 아주 독특한 디자인으로 변경할 경우 6,025 원을 더 지불할 의사가 있는 것으로 나타났다.

그리고 수목의 종류를 현재보다 20\% 정도만 다양하게 하여 도 4,599원의 추가 지불의사액이 발생하며, 일대일로 개별안내 를 할 경우 3,800 원의 추가 효용이 발생한다고 할 수 있다. 또

표 8. 환경서비스별 속성의 수준

\begin{tabular}{|c|c|c|c|c|c|c|}
\hline \multirow{2}{*}{ 구분 } & \multirow{2}{*}{ 효용계수 } & \multirow{2}{*}{ Std. Err } & \multirow{2}{*}{$z$} & \multirow{2}{*}{$\mathrm{P}\rangle|\mathrm{z}|$} & \multicolumn{2}{|c|}{$95 \%$ Conf. Interval } \\
\hline & & & & & Lower layer & Upper layer \\
\hline Personal guide & 0.7979 & 0.0877 & 9.10 & 0.000 & 0.6259 & 0.9697 \\
\hline Group guide & 0.2442 & 0.0863 & 2.83 & 0.005 & 0.7508 & 0.4132 \\
\hline Path design1 & 0.6775 & 0.0876 & 7.73 & 0.000 & 0.5057 & 0.8491 \\
\hline Path design2 & 0.5878 & 0.1142 & 5.15 & 0.000 & 0.3639 & 0.8116 \\
\hline Plant species1 & 0.9657 & 0.0895 & 10.78 & 0.000 & 0.7901 & 1.1411 \\
\hline Plant species2 & 0.7049 & 0.1152 & 6.12 & 0.000 & 0.4790 & 0.9307 \\
\hline Price & -0.00021 & 0.00008 & -2.58 & 0.01 & -0.0003 & -0.00005 \\
\hline Pseudo $\mathrm{R}^{2}$ & \multicolumn{6}{|c|}{0.1063} \\
\hline Log-Likelihood & \multicolumn{6}{|c|}{$-1,979.3124$} \\
\hline 관측수 & \multicolumn{6}{|c|}{3,510} \\
\hline
\end{tabular}

표 9. 수목원의 효용과 수준간의 지불의사액 추정 (단위: 원)

\begin{tabular}{c|c|c}
\hline 효용의 명칭 & 효용의 수준과 정의 & 편익의 가치(원) \\
\hline Personal guide & 일대일로 수목원의 안내와 수목에 대한 설명 & 3,800 \\
\hline Group guide & 단체로 수목원의 안내와 수목에 대한 설명 & 1,163 \\
\hline Path design1 & 원로의 디자인이 현재의 평범함에서 약간 독특한 디자인으로의 변화 가치액 & 3,226 \\
\hline Path design2 & 약간 독특한 원로 디자인에서 아주 독특한 디자인으로의 변화가치액 & 2,799 \\
\hline Plant species1 & 현재의 수준에서 수목의 종류가 20\% 향상시의 지불의사액 & 4,599 \\
\hline Plant species2 & 수목의 종류가 20\%에서 50\% 많아질 때의 지불의사액 & 3,357 \\
\hline
\end{tabular}


한 원로의 디자인을 현재의 수준에서 약간 독특한 수준으로 변 형시킨다면 3,226원의 효용이, 단체로 수목원의 안내와 설명을 할 경우는 1,163 원의 효용이 발생한다고 할 수 있다.

현재의 수준보다 수목의 종류가 $50 \%$ 다양해질 경우, 가장 많은 추가비용을 지불할 의사가 있음을 나타내고 있음을 유추 해보면, 방문객들은 수목원의 본연의 기능인 산림자원의 수 집·전시의 기능에 더 높은 효용의 가치를 느끼고 있음을 알 수 있다. 방문객들은 현재보다 더 울창한 숲 속에서 산책이나 수목에 대한 관상을 하기 기대하고 있음을 알 수 있다. 그리고 산책 동선의 다양한 설계로 호기심을 충족해 줄 수 있는 원로 의 디자인이 필요하다고 할 수 있다. 또한 현재 시행하고 있는 산림해설에 대한 가치를 비교해 보면 단체로 수목원에 대한 해 설과 안내를 해 주는 경우보다 개별로 안내를 해 줄 경우, 약 3 배 가량의 추가 효용이 더 발생한다고 볼 수 있다.

\section{V. 결과 및 고찰}

국민들에게 쾌적한 녹색 생활공간을 제공하는 산림환경의 조 성, 삼림휴양- 문화공간의 확충, 건강한 산림 생태계의 보전, 관 리, 신품종 개발 및 유지관리, 역사적 - 사회적 교육의 장 제공 등의 역할을 제공하는 수목원의 역할과 기능은 앞으로 더욱 중 요시 될 전망(하성근, 2007)이며, 이에 따른 수목원의 개별 기 능과 서비스에 대한 가치의 추정에 대한 연구의 필요성이 제기 되고 있다. 본 연구는 수목원이 방문객들에게 제공하는 물리적 시설과 서비스에 대한 개개의 가치를 금액으로 추정하여 비교 하기 위해 수행되었으며, 그 결과는 아래와 같다.

첫째, 경남수목원이 제공하는 물리적 시설과 서비스에 대한 각각의 가치를 화폐단위로 추정하고, 그 크기를 비교해 보고자 환경재의 가치추정방법 중의 하나인 선택실험법 $(\mathrm{CE})$ 을 이용 하였다. $\mathrm{CE}$ 기법은 효용의 크기를 화폐로 나타낼 수 있는 장점 이 있다.

둘째, 경남수목원의 물리적 시설과 서비스의 개별가치를 추 정하기 위한 속성은 수목의 종류, 원로의 디자인, 개별 또는 단 체를 대상으로 한 수목원 안내 등으로 한정하였다. 수목원의 물리적 시설이나 서비스 등은 이 외에도 많이 존재할 수 있지 만, 속성의 종류와 수준이 많아질수록 설문 프로파일이 기하급 수적으로 늘어나 효율적인 개별가치의 추정이 힘들기 때문에, 본 연구에서는 시험적 시도의 개념으로 접근하였다.

셋째, 설문을 위한 프로파일의 작성은 SPSS 통계패키지의 직교설계를 이용하여 25개의 프로파일을 추출하여 각각의 프 로파일이 중복되지 않도록 75쌍의 질문항을 만들어 2011년 5월 부터 2012년 4월에 걸쳐 경남수목원 이용객에게 직접설문하였 다. 관측된 자료는 1 인당 5 세트씩, 3 개의 문항을 질문하여 3,510 개의 자료를 분석에 이용하였다.
넷째, 현재의 수준을 기준으로 한 이용객의 지불의사액이 가 장 큰 속성은 현재보다 수목의 종류를 $50 \%$ 더 다양하게 하는 것이 7,956 원의 추가적 지불의사를 나타내고 있다. 그리고 두 번째가 현재의 원로 디자인보다 매우 독특한 디자인의 가치가 6,025 원으로 나타났으며, 수목원 관람 시 개인 안내원이 가이드 를 해 주는 것이 단체로 안내해 주는 것보다 약 3 배 정도 더 많 은 추가비용을 지불할 의사가 있는 것으로 나타났다. 이를 통 해 경남수목원의 이용객들이 가장 가치를 높게 인식하는 것은 수목원 본래의 기능인 수목의 수집과 전시기능에 가장 높은 효 용가치를 느끼고 있음을 알 수 있으며, 그 다음으로 다양하고 울창한 수목을 잘 관찰할 수 있는 독특한 원로의 디자인에 그 가치를 두고 있음을 알 수 있다. 따라서 향후 경남수목원에서 이용객에게 더 나은 편의를 제공하여 이용만족도와 수목원 본 래의 기능을 증진시키려 한다면 이와 같은 우선순위를 토대로 시설과 서비스의 개선작업을 하여야 할 것이다.

수목원에서 이용객에게 제공할 수 있는 서비스는 물리적 시 설과 문화적 시설이라고 할 수 있다. 물리적 시설은 수목의 종 류, 편의시설, 원로의 디자인, 시설물의 청결 등이며, 문화적 시 설은 이용객 관련 프로그램, 직원의 친절, 수목 코디네이터 양 성 프로그램, 숲해설 제공 등으로 구분해 볼 수 있다. 이들 서 비스는 수목원에서 일반적으로 제공되는 서비스이지만, 각각의 서비스가 이용객에게 어느 정도의 효용을 제공하는지에 대한 구체적인 화폐가치로 추정하기는 쉽지 않다.

환경재 또는 공공재의 가치추정은 초기 경제학자들의 호기 심으로부터 시작되었다고 할 수 있다. 이러한 호기심은 여행비 용법, 헤도닉가격법, 회피행위지출법 등을 거쳐 $\mathrm{CVM}$ 과 $\mathrm{CE}$ 기 법으로 발전해 왔다. 이러한 발전의 이면에는 계량경제학자들 의 예측식을 이용한 방법론의 적용으로 좀 더 신뢰성 있는 추 정법으로 변화해 왔다. 하지만 이러한 한경재의 가치추정 방법 이 거래할 수 없는 재화에 대해 가격을 산정하는 하는 일이기 때문에, 추정액에 대해 맞거나 틀리거나를 명확히 확정지을 수 없는 원초적인 한계점이 있다. 따라서 이에 대한 좀 더 세밀한 연구들이 진행되어야 할 것이다.

본 연구에 있어서도 수목원에서 제공할 수 있는 전체의 환경 가치를 추정한다면 CVM 기법으로 가능하지만, 수목원을 구성 하고 있는 환경재의 개개의 가치를 추정하고자 한다면 $\mathrm{CE}$ 기 법을 적용하는 것이 더 명확한 결과를 도출할 것이다. 하지만 $\mathrm{CE}$ 기법을 적용하여 전체의 합을 더하면 일반적인 환경재의 가치는 상승하게 된다. 따라서 향후의 $\mathrm{CE}$ 기법을 적용할 경우 는 전체의 환경재의 가치를 구하기보다는 환경재를 구성하고 있는 속성들 간의 비교우위를 선정할 경우에 적용하는 것이 바 람직하다고 판단되며, 이에 대한 향후의 연구들이 이루어져야 할 것으로 사료된다.

본 연구는 이러한 수목원의 다양한 서비스기능들 중 이용객 
이 인식하는 효용가치를 화폐액으로 추산하여 그 크기를 비교 해 보고자 수행되었다. 분석의 도구는 상충효과를 이용한 선택 실험법을 응용하였다. 선택실험법의 장점은 환경재의 가치를 개별적으로 추정해 낼 수 있다는 점이지만, 단점은 환경재를 이루고 있는 속성의 종류와 수준을 어느 정도로 조절해야 추정 하고자 하는 환경재의 적절한 범위인지에 대한 명확한 기준이 없다는 점이다. 이러한 단점을 가지고 있지만, 수목원 운영 주 체에서 알고자 하는 이용객의 특정한 효용의 가치를 비교 또는 측정해 보고자 할 경우 매우 유용한 방법이 될 수 있을 것이며, 본 연구는 이러한 개별 환경재의 가치추정에 대한 기본적인 선 행연구로서의 의미를 가진다고 할 수 있다.

\section{인용문헌}

1. 강기래(2010) 강기래(2010) 자연휴양림 보존가치 측정을 위한 조건부가 치측정법(CVM) 추정액 비교. 한국조경학회지 $38(2)$ : 25-36.

2. 강기래, 하성근, 이기철(2011) 가상가치측정법 $(\mathrm{CVM})$ 을 이용한 경남수 목원의 환경가치추정연구. 한국조경학회지 39(1) : 46-55.

3. 강기래(2012) 대구수목원 이용객 만족모델을 통한 운영방안 연구. 한국 임학회지 101(1): 36-45.

4. 국립수목원(2004) 수목원 운영전문화를 위한 워크샵 자료.
5. 나정화(2000) Hemeroby 등급을 적용한 수목원 조성 전후의 자연성평 가:대곡수목원을 대상으로. 한국조경학회지 28(1): 62-69.

6. 노형진. 2001. 한글 SPSS10.0에 의한 조사방법 및 통계분석. 서울 : 형설 출판사.

7. 박주헌(2000) 환경경제학. 서울: 경문사.

8. 백동렬, 정용문, 변재상(2003) 충남금강수목원의 이용실태 및 활성화에 관한 연구. 한국환경복원기술학회지 6(6): 14-24.

9. 이창복(1972) 수목원. 산림 77(0): 24-27.

10. 이총규, 구관효, 황용우, 윤석락, 김종갑(2007) 경상남도수목원내 수목의 가해해충 분포. 농업생명과학연구 40(3): 47-54.

11. 임양재, 조무연(1977) 홍릉수목원수종의 개화기에 관하여. 한국생태학회 지 1(1): 17-43.

12. 임연진, 배준규, 주진순, 김현중(2005) 국립수목원 방문객의 이용행태 및 만족도 분석. 한국산림휴양학회지 9(2): 21-27.

13. 조우, 장종수, 민성환, 오강임(2003) 인천광역시 수목원 조성기본계획. 한국조경학회지 31(5): 96-107.

14. 하성근(2007)수목원 기능별 지표의 중요도와 특성화 방안. 경북대학교 석사학위논문.

15. 홍성권, 김재현, 김용하, 김성진, 장호찬, 이석호, 태유리(2010) 신택실험 법을 이용한 수목원의 경제가치 추정. 한국임학회지 99(4): 517-527.

16. Haab, T. C. and K. E. McConnell(2002) Valuing Environmental and Natural Resources: The Economics of Non-Market Valuation, Edward Elgar.

17. Hanemann, W. M. (1984) Welfare evaluation in contingent valuation experiments with discrete responses. American Journal of Agricultural Economics. 71(3) : 1057-1061.

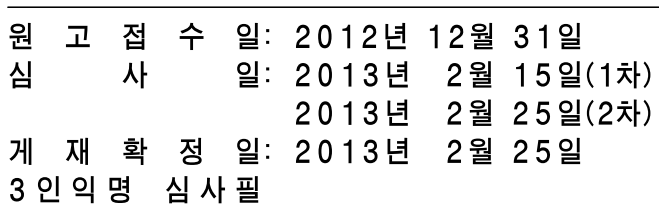

